\title{
In-vitro Investigation of Imidaclopride effects on AChE, LDH and GSH levels in L-929 Fibroblast Cell Line
}

\section{CIGDEM SEVIM $^{1}$, Ali TAGHIZADEHGHALEHJOUGHİ ${ }^{2}$, Mehtap Kara $^{2}$}

${ }^{1}$ Istanbul University Faculty Of Pharmacy Department Of Pharmaceutical Toxicology, Istanbul, Turkey

${ }^{2}$ Ataturk University, Veterinary Faculty, Department of Pharmacology and Toxicology, Erzurum, Turkey

\begin{abstract}
INTRODUCTION: There are several type of pesticides to control pests and several new type of pesticides come into use that could less toxic compared to old ones. Pesticide induced oxidative stress which is one of the main mechanism of toxicity, mostly focused research area in the last decade. There are several different studies in the literature on whether pesticide exposure induce oxidative stress parameters mediated toxicity...Pesticide induced oxidative stress level depends on biochemical feature of mammalian systems. Imidacloprid is a neonicotinoid pesticide which widely use that considered safe, however it has been reported in different studies that imidacloprid may cause changes oxidative stress parameters.
\end{abstract}

METHODS: Thus, in this study we aimed to investigate dose and time dependent imidaclopride effects on AcHE, LDH and GSH levels in L-929 fibroblast cell line. 1-500 $\mu \mathrm{g}$ imidaclopride dose range effects on acetylcholinesterase, glutathione and lactat dehidrogenase were investigated in this study.

RESULTS: LDH levels were significantly increased dose dependently in 250 and $500 \mathrm{ng}$ imidaclopride compared to control group. GSH levels non-significantly decreased dose dependently and GSH levels were decreased in $500 \mathrm{ng}$ imidaclopride group compared to control. There were no significant difference between groups for acetylcholinesterase levels.

DISCUSSION AND CONCLUSION: These results indicated that high doses imifoclopride may induce oxidative stress parameters in fibroblast cells.

Key Words: Imidaclopride, L-929 cell line, Oxidative stres, AChE

Özet

GİRIŞ VE AMAÇ: Çok çeşitlilikte pestisit türleri zararlıları kontrol etmek amacı ile bulunmakta ve pek çok yeni tür pesitisitte daha az toksik olması amaçlanarak kullanıma girmektedir. Toksisite mekanizmalarında önemli rol alan pestisit uyarımlı oksidatif stress, son on yıłda en çok odaklanılan araştırma alanı olarak karşımıza çıkmaktadır. Literatürde pestisitlerin oksidatif stres aracılık toksisiteyi uyarıp uyarmadığına yönelik çok sayıda çalışma bulunmaktadır. Pestisit nedenli oksidatif stres seviyesi, memeli sistemlerin biyokimyasal özelliklerine bağımlıdır. İmidacloprid güvenilir oldugu varsayılan bir neonikotinoid türü pestisittir,ancak farklı çalışmalarda imidaclopridin oksidatif stres parametrelerini değiştirdiği bildirilmiştir.

YÖNTEM VE GEREÇLER: Bu çalışmada doz ve süre bağımlı olarak imidaclopridin L-929 fibroblast hücrelerinde AcHE, LDH ve GSH parametreleri üzerine etkisini inceledik. 1-500 $\mu \mathrm{g}$ imidacloprid dozlarının asetilkolinesteraz, glutatyon ve laktat dehidrojenaz üzerine etkileri araştırıldı.

BULGULAR: 250 ve 500 ng imidaclopridin LDH seviyelerini, kontrol grubuna kıyasla anlamlı olarak artırdığı tespit edildi. GSH seviyeleri dozdan bağımsız olarak 500ng imidacloprid dozunda kontrol grubuna kıyasla anlamlı olarak azaldığı tespit edildi. Asetilkolinesteraz seviyeleri arasında anlamlı bir fark gözlenmedi.

TARTIŞMA VE SONUÇ:Bu sonuçlara göre yüksek doz imidacloprid maruziyeti fibroblast hücrelerinde oksidatif stres parametrelerini uyarabileceğigözlemlenmiştir.

\section{Abbreviations:}

AChE Acetylcholinesterase

DMEM Dulbecco's Modified Eagle’s Media

DMSO Dimethyl sulfoxide 
ELISA Enzyme-Linked ImmunoSorbent Assay

GSH Glutathione

LD50 Lethal dose 50

LDH Lactate Dehydrogenase

Kısa Başlık: Imidaclopride Induced Oxidative Stress

\section{Introduction}

Pesticides are mixtures of substances used to prevent, control or reduce harmful organisms. Pesticides include active substances and filling material that facilitate usage and increase effect of active substances. Commercially available drugs are manufactured and launch to market with its mixed form with filling material. In Turkey 2500 tons pesticides used every year ( 1-3).

It has been speculated that, neonicotinoid pesticides exhibit much lower toxic effects on mammals than insects, and therefore replace organophosphates and carbamate insecticides. Neonicotinoid pesticides are at increased risk for humans due to often used not only in agricultural applications but also in the removal of domestic pests. Neonicotinoid pesticides show their selective toxic effects on insects via nicotinic acethylcholine receptors. Imidaclopride which is a member of a new neuroactive neonicotinoid insecticide class, is commonly used insecticide worldwidwe and also in Turkey. It has been reported that 120 country use commonly imidaclopride since 1990 that was first introduced commercially. It has been reported that, imidaclopride's oral LD50 values for rats $380-650 \mathrm{mg} / \mathrm{kg}$ of body weight and for mice $130-170 \mathrm{mg} / \mathrm{kg}$ of body weight, respectively. Under aerobic conditions, imidaclopride is environmental persistent chemical with its 3-year half-life which increase risk. (4-7).

Pesticide-induced oxidative stress has been the focus of toxicological research over the last decade as a possible mechanism of toxicity. Several studies have been conducted to determine whether oxidative stress in humans or animals is caused by various agents in this group and is related to their toxic effects $(\mathbf{8 , 9})$. It has been reported in different studies that imidaclopride induce oxidative stress parameters imbalance in different organisms in-vitro and in-vivo (10-17), however there are no study on imidaclopride's oxidative imbalance effects on fibroblast tissue in the literature.

In this study we aimed to investigate in-vitro effects of imidaclopride on AcHE, LDH and GASH parameters in L929 fibroblast cell line.

\section{Materials-Methods}

Chemicals: Dulbecco's Modified Eagle's Media (DMEM), fetal bovine serum (FBS), phosphate-buffered saline (PBS), penicilin streptomycin solution, and trypsin-EDTA solution were purchased from Sigma-Aldrich Co. (St. Louis, MO, USA), Imidaclopride was purchased from Acetylcholinesterase Assay Kit (Fluorometric Red, ab138873), Lactate Dehydrogenase (LDH) Assay Kit (Fluorometric, ab197000), and Glutathione Assay Kit (Fluorometric, ab65322) were purchased from Abcam, (Cambridge, UK) L929 cell line (CRL-6364) was purchased from the American Type Culture Collection (ATCC, VA, USA). Imidaclopride-based herbicide (GORTCA FS 600) was purchased from Safa Tarım LTD, Turkey and contained pure imidaclopride (CAS Number: 138261-41-3, Product code: 0210-207) was used in the experiments.

Cell Culture and Treatments:All experiments on L929 were performed within 20 passages. The cells were grown with DMEM containing $10 \%$ of FBS and $1 \%$ penicilin-streptomycin-amphotericin B in a humidified incubator supplied with $5 \%$ of $\mathrm{CO} 2$ at $37^{\circ} \mathrm{C}$. Before conducting the treatments, the cells were cultured for $24 \mathrm{~h}$ to ensure attachment.

The L-929 cells were incubated with imidaclopride which were dissolved in $100 \%$ of dimethyl sulfoxide (DMSO) and diluted with medium to the desired concentrations as $500 \mu \mathrm{g}, 250 \mu \mathrm{g}, 125 \mu \mathrm{g}, 50 \mu \mathrm{g}, 25 \mu \mathrm{g}, 5 \mu \mathrm{g}$ and $1 \mu \mathrm{g}$. Studies reported that cytotoxicity is observed at concentrations higher than $500 \mathrm{ug} / \mathrm{ml}$. In present study high concentration of imidacloprid determined as 500.(18). Vehicle control cells received equal volume of $\operatorname{DMSO}(0.5 \%)$ as the treatments for $24 \mathrm{~h}$. LDH, GSH and AChE assays were performed after $24 \mathrm{~h}$ exposure. 
LDH and GSH Parameters:_Lactate dehydrogenase (LDH) is a cytosolic enzyme and the measurement of its leakage to the extracellular matrix due to cell membrane damage is an indicator of cell membrane integrity loss and oxidative stres (19).

For this purpose, the L-929 cells were plated in 96-well plates at 1x10 cells/well and grown for $24 \mathrm{~h}$. Following cell treatments, the LDH release in supernatants due to membrane damage was quantified using a rat LDH ELISA kit (Cat. Number: E-EL-R2547) in accordance with the manufacturer's protocol. 100 $\mu 1$ standard or sample were added to each well then incubate 90 minutes at $37^{\circ} \mathrm{C}$. After removed the liquid, $100 \mu 1$ Biotinylated Detection $\mathrm{Ab}$ added and incubated 1 hour at $37^{\circ} \mathrm{C}$. Following aspiration and washing 3 times, $100 \mu \mathrm{HRP}$ Conjugate added and incubated 15 minutes at $37^{\circ} \mathrm{C}$. Following aspiration and washing 5 times, $90 \mu \mathrm{l}$ Substrate Reagent added and incubated 15 minutes at $37^{\circ} \mathrm{C}$. When $50 \mu \mathrm{l}$ Stop solution added, it read at $450 \mathrm{~nm}$ using microplate reader (Biotek Epoch, USA).

GSH is an important molecule for the cellular antioxidant system and under oxidative stress conditions GSH level decreases (Robaczewska J et al., 2016). The L-929 cells were cultured in $25 \mathrm{~cm}^{2}$ flasks to determine GSH levels. Following cell imidaclopride exposure, $1 \times 10^{6}$ cells were harvested in $1 \mathrm{~mL}$ of PBS and were homogenized by sonication, and the GSH content of L-929 cells was determined using the GSH (Glutathione) ELISA kit (Cat. Number: E-EL-0026) to assay human GSH following the manufacturer's procedure and referred

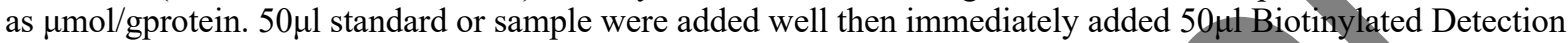
$\mathrm{Ab}$ to each and incubate 45 minutes at $37^{\circ} \mathrm{C}$. Following aspiration and washing 3 times, $100 \mu \mathrm{l} \mathrm{HRP}$ Conjugate added and incubated 30 minutes at $37^{\circ} \mathrm{C}$. Following aspiration and washing 5 times, $90 \mu$ Substrate Reagent added and incubated 15 minutes at $37^{\circ} \mathrm{C}$. When $50 \mu \mathrm{l}$ Stop solution added, it read at $450 \mathrm{~nm}$ using micro-plate reader (Biotek Epoch, USA).

Acetylcholinesterase Assay: The AChE is strikingly distributed in cell-substrate interface of radiated and migrating fibroblasts (Morphoregulation by acetylcholinesterase in fibroblasts and astrocytes.) and it helps to understand the nervous system work properly. The L-929 cells were cultured in $25 \mathrm{~cm}^{2}$ flasks to determine Acetylcholinesterase levels. Following cell imidaclopride exposure, $1 \times 10^{6}$ cells were harvested in $1 \mathrm{~mL}$ of PBS and were homogenized by sonication, and the Acetylcholinesterase content of L-929 cells was determined using the Acetylcholinesterase Assay Kit (Colorimetric, Cat. number: ab138871) $50 \mu$ l of acetylcholinesterase reaction mixture added into each well of acetylcholinesterase standard, blank control, and test samples to make the total acetylcholinesterase assay volume of $100 \mu \mathrm{l} /$ well then incubated the reaction for 30 minutes at room temperature. Increased fluorescence monitored absorbance $\mathrm{OD}$ at $140 \mathrm{~nm}$ with micro-plate reader (Biotek Epoch, USA).

Statistical Analysis:All the experiments were performed as three replicates and the results were presented as the mean \pm standard deviation. The statistical comparisons were evaluated using the One-way ANOVA analysis of variance followed by the Tukey's test for post hoc analysis, and the statistical significance was set at $p<0.05$ (SPSS, version 21.0, USA).

\section{Results}

LDH results of imidaclopride exposure on L929 cells were shown in Figure 1. We observed that LDH levels were increased dose dependently. 250 and $500 \mathrm{ng}$ imidaclopride increased LDH levels statistically significant compared to control group. GSH results of imidaclopride exposure on L929 cells were shown in Figure 2. GSH levels non-significantly decreased dose dependently and GSH levels were decreased in $500 \mathrm{ng}$ imidaclopride group compared to control. AChE results of imidaclopride exposure on L929 cells were shown in Figure 3. There were no significant difference between groups, however AChE level nonsignificant decreased in $125 \mathrm{ng}$ group.

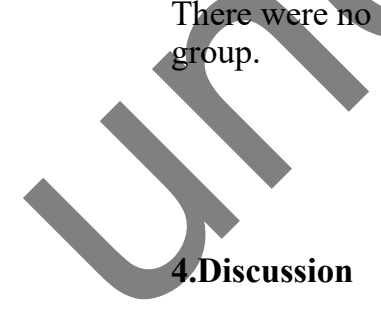

Neonicotionids as a worldwide popular pesticides that usage of them have increased since 2000. neonicotinoids show their effects on insects via cellular nAChR mechanism (20,21). In recent years, neonicotinoids takes pyrethroid, organophosphorus and carbamate insecticides places in the usage (22). It is believed that neonicotinoids are safe pesticide group for non-target species, however there are several recent study in the literature about neonicotinoids different toxic effects on non-target organisms $(23,24)$. 
)Stable cytoplasmic enzyme lactate dehydrogenase ( $\mathrm{LDH})$ is an important biomarker for oxidative stress, apoptosis, necrosis, and other forms of cellular damage, expressed in all cells and rapidly released when the plasma membrane is damaged. In a study conducted in 2018, Kumar et al., showed that LDH level increased with cellular damage in accordance with our study $(25,26)$. Abu Zaid et al., reported that imidaclopride exposure in Rock pigeon (Columba livia domestica) resulted with significant increase of plasma LDH levels in high dose $(6 \mathrm{mg} / \mathrm{kg})$ and median dose $(3 \mathrm{mg} / \mathrm{kg})$ imidaclopride groups, however there were no significant increase in low dose $(2 \mathrm{mg} / \mathrm{kg})$ group compared to control group. Plasma AChEs enzyme activities in all imidaclopride dose groups significantly increased compared to control group (27). Lonare $\mathrm{M}$ et al., demonstrated that 28 days, 45 and $90 \mathrm{mg} / \mathrm{kg}$ body weight oral exposure of imidaclopride significantly decreased AChE level in rats erythrocytes. In addition, Brain AChE activity in rats of imidaclopride treatment groups dose dependant compared to control group. Also they demonstrated that LDH levels increased and GSH levels decreased significantly imidaclopride treated grops in different tissues of rats (28). Tian et al., showed that imidaclopride exposure in Chinese rare minnows brain increased $\mathrm{GSH}$ and the $\mathrm{AChE}$ activities. This results indicate that imidaclopride have no effect on Chinese rare minnows (11). Topal et al, demonstrated that imidaclopride have neurotoxic effects thruogh AChE inhibition, and induce oxidative stres in rainbow trout brain tissue (29). It has been reported that imidaclopride exposure significantly decreased AChE levels in plasma and brain of 10 and 20 $\mathrm{mg} / \mathrm{kg}$ treated female rats (30). In another study 24 hours $20 \mathrm{mg} / \mathrm{kg}$ imidaclopride administration decreased AchE activity approximately $22 \%$ in brain and $28 \%$ in red blood cells (31).

Thus, studies about imidaclopride effects on AchE, LDH and GSH Express contraversial results which may related with different study conditions as species variety, exposure time variety, in-vitro and in vivo condutions and different doses. There are studies that include oxidative stress parameters inducing effect of imidaclopride with different species in the literature, however underlying mechanism is stil not elucidated yet. Further studies needed to clarify toxic effects of neonicotinoids specially imidaclopride in different species and in different tissues.

\section{References:}

\section{References:}

1- Cha YS, Kim H, Lee Y, Choi EH, Kim HI, Kim OH, Cha KC, Lee KH et al. 2017 The relationship between serum ammonia level and neurologic complications in patients with acute glufosinate ammonium poisoning: A prospective observational study. Hum Exp Toxicol. 1:960327117715902.

2- Park S, Kim DE, Park SY, Gil HW and Hong SY 2017 Seizures in patients with acute pesticide intoxication, with a focus on glufosinate ammonium. Hum Exp Toxicol. 1:960327117705427.

3- Calas AG, Perche O, Richard O, Perche A, Pâris A, Lauga F, Herzine A, Palomo J et al. 2016 Characterization of seizures induced by acute exposure to an organophosphate herbicide, glufosinateammonium. Neuroreport. 27 532-41.

4- Kavvalakis MP, Tzatzarakis MN, Theodoropoulou EP, Barbounis EG, Tsakalof AK and Tsatsakis AM 2013 Development and application of LC-APCI-MS method for biomonitoring of animal and human exposure to imidacloprid. Chemosphere. 93 2612-20.

5- Kim J, Park Y, Yoon KS, Clark JM and Park Y 2013 Imidacloprid, a neonicotinoid insecticide, induces insulin resistance. J Toxicol Sci. 38 655-60

6- Park Y, Kim Y, Kim J, Yoon KS, Clark J, Lee J and Park Y. 2013 Imidacloprid, a neonicotinoid insecticide, potentiates adipogenesis in 3T3-L1 adipocytes. J Agric Food Chem. 61 255-9

7- Tomizawa M and Casida JE 2000 Imidacloprid, thiacloprid, and their imine derivatives up-regulate the alpha 4 beta 2 nicotinic acetylcholine receptor in M10 cells. Toxicol Appl Pharmacol. 169 114-20 Etemadi-Aleagha A, Akhgari M and Abdollahi M, 2002 A brief review on oxidative stress and cardiac diseases. Mid. East Pharm. 10 8-9

9- Abdollahi M, Ranjbar A, Shadnia S, Nikfar S and Rezaie A 2004 Pesticides and oxidative stress: a review. Med. Sci. Monit., 10 141-147

10- Wang Y, Han Y, Xu P, Guo B, Li W and Wang X 2018 The metabolism distribution and effect of imidacloprid in chinese lizards (Eremias argus) following oral exposure. Ecotoxicol Environ Saf. 165 476-483.

11- Tian X, Yang W, Wang D, Zhao Y, Yao R, Ma L, Ge C, Li X, et al 2018 Chronic brain toxicity response of juvenile Chinese rare minnows (Gobiocypris rarus) to the neonicotinoid insecticides imidacloprid and nitenpyram. Chemosphere. 210 1006-1012

12- Njattuvetty Chandran N, Fojtova D, Blahova L, Rozmankova E and Blaha L 2018 Acute and (sub)chronic toxicity of the neonicotinoid imidacloprid on Chironomus riparius. Chemosphere. 209 568-577. 
13- Shakir SK, Irfan S, Akhtar B, Rehman SU, Daud MK, Taimur N and Azizullah A 2018 Pesticideinduced oxidative stress and antioxidant responses in tomato (Solanum lycopersicum) seedlings. Ecotoxicology. 27 919-935.

14- Özdemir S, Altun S and Arslan H 2017 Imidacloprid exposure cause the histopathological changes, activation of TNF- $\alpha$, iNOS, 8-OHdG biomarkers, and alteration of caspase 3 , iNOS, CYP1A, MT1 gene expression levels in common carp (Cyprinus carpio L.). Toxicol Rep. 27 125-133.

15- Wang X, Anadón A, Wu Q, Qiao F, Ares I, Martínez-Larrañaga MR, Yuan Z and Martínez MA 2018 Mechanism of Neonicotinoid Toxicity: Impact on Oxidative Stress and Metabolism. Annu Rev Pharmacol Toxicol. 6 471-507

16- Kapoor U, Srivastava MK, Bhardwaj S and Srivastava LP 2010 Effect of imidacloprid on antioxidant enzymes and lipid peroxidation in female rats to derive its No Observed Effect Level (NOEL). $J$ Toxicol Sci. 35 577-81

17- International Programme on Chemical Safety Toxicological evaluations: Imidacloprid, 2001; http://www.inchem.org/documents/jmpr/jmpmono/2001pr07.htm, 2011

18- California Environmental Protection Agency/Department of Pesticide Regulation; Summary of Toxicology Data, Imidacloprid (138261-41-3) p. 5-6 (May 24, 1993, Revised November 18, 2013). Available from, as of January 15, 2016

19- Jovanovic P, Zoric L, Stefanovic I, Dzunic B, Djordjevic-Jocic J, Radenkovic M and Jovanovic M. 2010 Lactate dehydrogenase and oxidative stress activity in primary open-angle glaucoma aqueous humour. Bosn J Basic Med Sci. 10 83-8

20- Casida JE and Durkin KA 2013 Neuroactive insecticides: targets, selectivity, resistance, and secondary effects. Annu. Rev. Entomol. 58 99-117

21- Wood TJ, Goulson D 2017 The environmental risks of neonicotinoid pesticides: a review of the evidence post Environ Sci Pollut Res Int. 24 17285-17325

22- Tankiewicz M, Fenik J and Biziuk M 2010 Determination of organophosphorus and organonitrogen pesticides in water samples. Trac. Trends Anal. Chem. 29 1050-1063

23- Tennekes HA and Sanchez-Bayo F 2011 Time-dependent toxicity of neonicotinoids and other toxicants: implications for a new approach to risk assessment J, Environ. Anal. Toxicol. S4 1-8

24- Whitehorn PR, O'connor S, Wackers FL and Goulson D 2012 Neonicotinoid pesticide reduces bumble bee colony growth and queen production Science 336 351-2

25- Shi DY, Xie FZ, Zhai C, Stern JS, Liu Y and Liu SL 2009 The role of cellular oxidative stress in regulating glycolysis energy metabolism in hepatoma cells. Mol Cancer. 5 8:32.

26- Kumar P, Nagarajan A and Uchil PD 2018 Analysis of Cell Viability by the Lactate Dehydrogenase Assay. Cold Spring Harb Protoc. 6 pdb.prot095497

27- Abu Zeid EH, Alam RTM, Ali SA and Hendawi MY 2018 Dose-related impacts of imidacloprid oral intoxication on brain and liver of rock pigeon (Columba livia domestica), residues analysis in different organs. Ecotoxicol Environ Saf. $560-68$.

28- Lonare M, Kumar M, Raut S, Badgujar P, Doltade S and Telang A 2014 Evaluation of imidaclopridinduced neurotoxicity in male rats: a protective effect of curcumin. Neurochem 78 122-9

29- Topal A, Alak G, Ozkaraca M, Yeltekin AC, Comaklı S, Ac1l G, Kokturk M and Atamanalp M 2017 Neurotoxic responses in brain tissues of rainbow trout exposed to imidacloprid pesticide: Assessment of 8-hydroxy-2-deoxyguanosine activity, oxidative stress and acetylcholinesterase activity. Chemosphere. 175 186-191.

30- Vohra P, Khera KS and Sangha GK 2014 Physiological, biochemical and histological alterations induced by administration of imidacloprid in female albino rats. Pestic Biochem Physiol. 110 50-6.

31- Kapoor U, Srivastava MK, Trivedi P, Garg V and Srivastava LP. Disposition and acute toxicity of imidacloprid in female rats after single exposure 2014. Food Chem Toxicol. 68 190-5. 


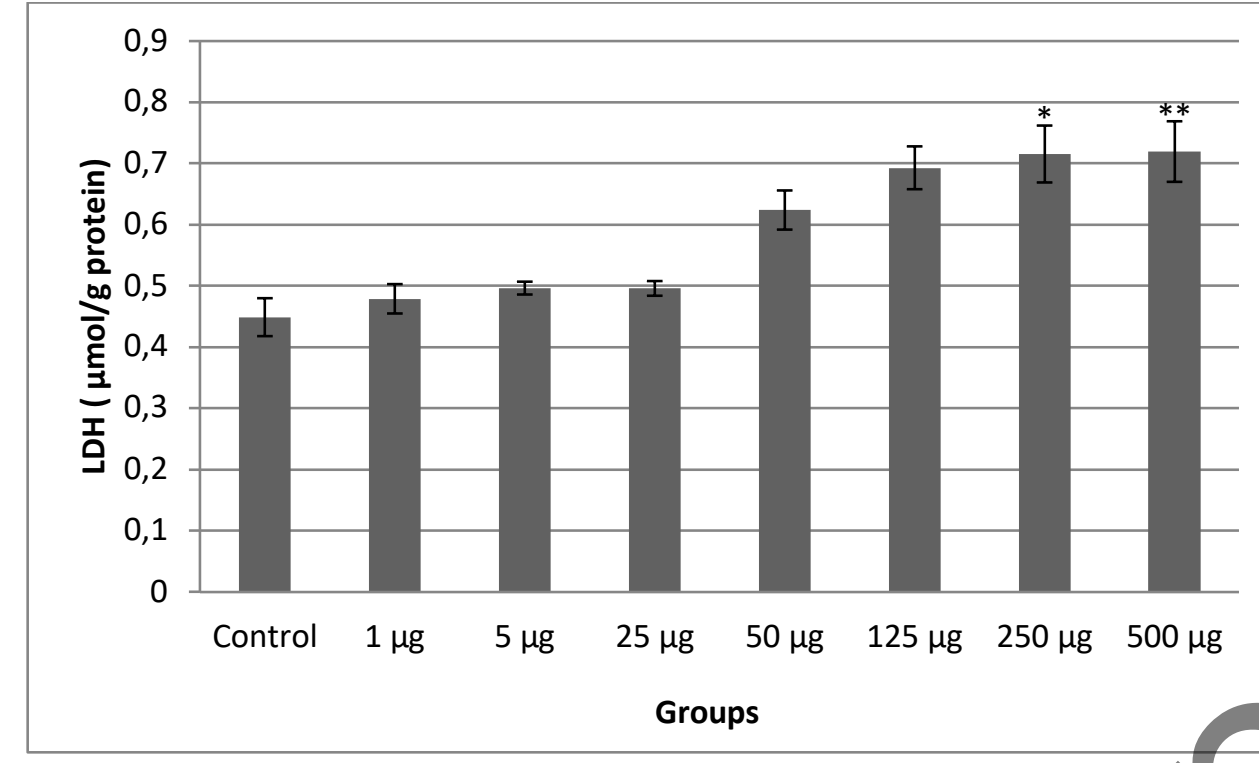

Figure Legend:

Figure 1. LDH level in L-929 cells with imidaclopride exposure.

Figure 2:

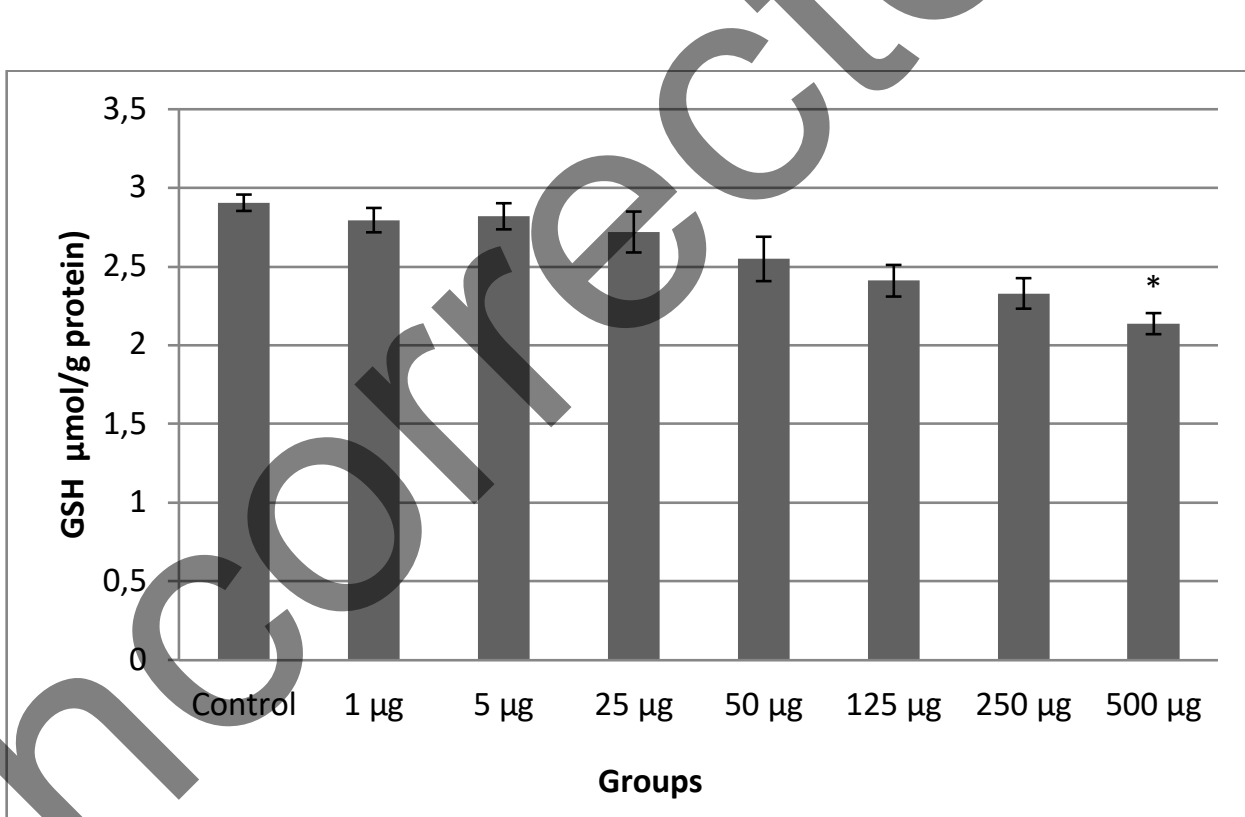

Figure Legend:

Figure 2. GSH level in L-929 cells with imidaclopride exposure.

Figure 3: 


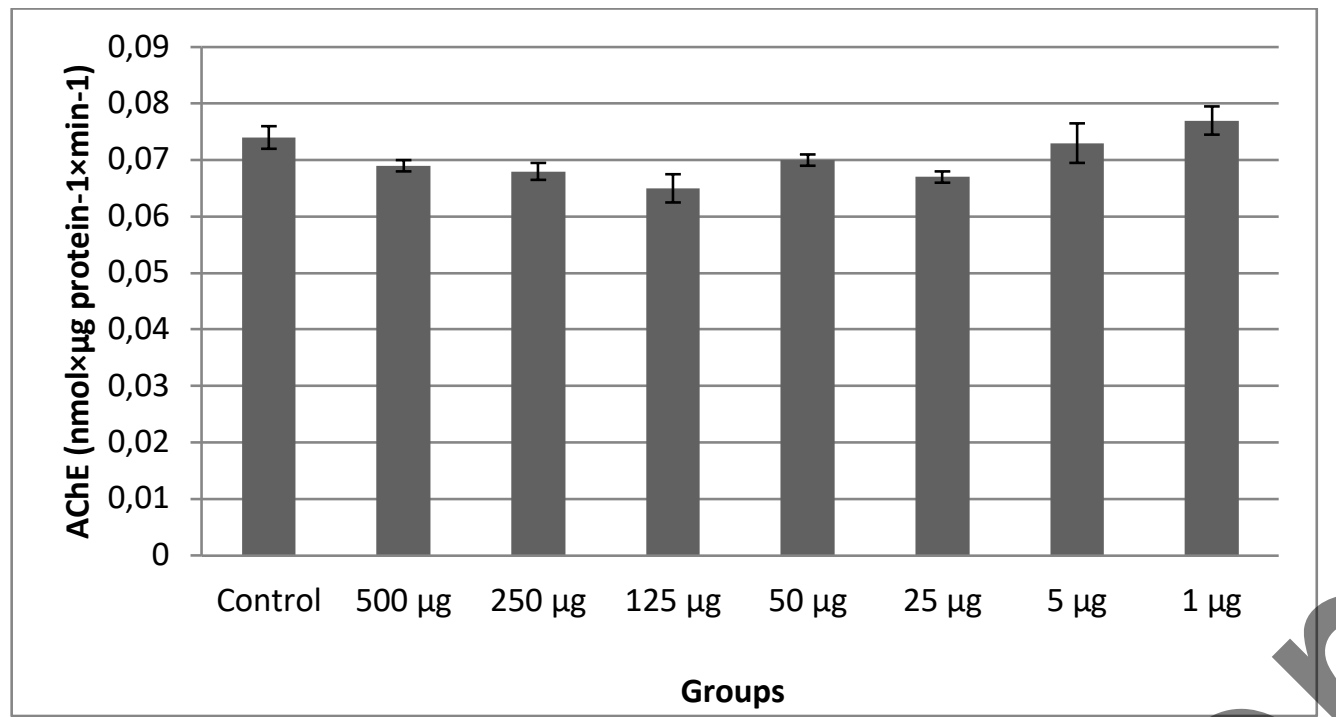

Figure Legend:

Figure 3. AChE level in L-929 cells with imidaclopride exposure. 